\title{
NOTES ON SOME BASIC PROBLEMS IN INELASTIC ANALYSIS OF PLANAR R/C STRUCTURES
}

\author{
(PART II)
}

by Haruo TAKIZAWA*, Member of A.I.J.

The paper (Part II) discusses several basic problems concerning nonlinear modeling techniques of structural constituent members, which is preceded by the other paper (Part I) .**

\section{SOME COMMENTS ON THE VALIDITY OF INELASTIC BEAM MODELINGS}

Several inelastic beam modeling techniques summarized in Part $I * *$ of this paper were originally developed in very different appearences in their respective ways of representing nonlinear beam characteristics. However, the subsequent discussions in Part. I have revealed that it is possible to treat these diversified techniques in a unified and definite manner by representing each flexibility matrix in terms of end flexibilities $f_{A}$ and $f_{B}$ defined for the antisymmetric loading of the given member. These flexibilities are well specified by introducing the notion of pseudo antisymmetric rotation.

This unified way of expressing each flexibility matrix enables one to carry out detailed comparative discussions on the properties inherent to a particular inelastic beam model. In or der to clarify the differences among these models from the viewpoint of examining the mechanical validity of modeling, one should compare the respective characteristics of stiffness reduction under particular loading conditions, endowing each beam model with identical properties for $f_{A}$ and $f_{B}$.

In this direct comparison, the problem may be divided into two parts. One is the simpler discussion under a certain particular loading condition with fixed position of inflection point, which will be dealt with later in this section. The other covers a general and complicated situation; the beam is subjected to a certain loading history of bending moment with time-variant shift of instantaneous inflection point.

Prior to discussi-ng the former case, some remarks are mentioned on substantial and fatal drawback or contradiction pertient to, and unavoidable in, any inelastic beam modelings. The substance of beam modeling the can be briefly stated as follows.

$\infty \times \infty$ degrees of freedom on stiffness information in the directions of member axis and beam depth, from the standpoint of stress-strain relationship in continuum mechanics

(Bernoulli-Euler's assumption)

$\infty \times 1$ degrees of freedom on stiffness information; i.e., $\infty$ in the direction of member axis and 1 in the direction of beam depth, from the standpoint of moment-curvature relationship in elementary beam theory

(Inelastic beam modeling)

$2 \times 1$ degrees of freedom on stiffness information in the relationship of end moment-end rotation at two member ends

* Department of Architecture, Faculty of Engineering, Hokkaido University.

** H. Takizawa, 'Notes on Some Basic Problems in Inelastic Analysis of Planar R/C Structures.; Trans. AIJ, 240, Feb. 1976, pp. 35-46. 
Namely the inelastic beam modeling may be interpreted as the drastic reduction of the degrees of freedom from $\infty \times \infty$ to 2 , in the instantaneous stiffness governing inelastic behavior of beam element. Accompanying this extreme simplification, certain unreasonableness is inevitably incurred. This defect will be not so serious, especially from a practical viewpoint, in case the beam is subjected to monotonically increasing or decreasing loading and unloading with nearly fixed or slowly varying position of inflection point. On the other hand, the inappropriateness may be conspicuous in a complicated loading process, where considerable shift of inflection point occurs instantaneously at some stages during the process.

As a simple example, the transitional process from the state of bending moment distribution indicated by full line to that by broken line in Fig. 11 is taken up. The instantaneous stiffnesses at both member ends $A$ and $B$ are elastic (unloaded at end $A$ ). Consequently any beam model judges automatically

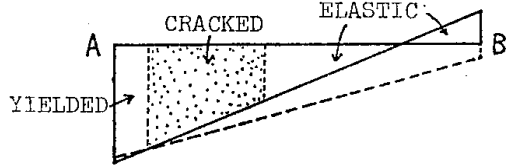

Fig. 11 An Example of Misjudgement on Member Characteristics that the member has elastic instantaneous rigidities at all sections along member axis. On the contrary, actual rigidities in the cracked region cannot be elastic, since $M \times d M$ in the region is positive (i.e., in loading) and moreover this region is developing. This misjudgement is a natural consequence of the assumption that rigidities at all intermediate sections be determined implicitly by only the two stiffnesses at member ends. As clearly shown in this example, any beam model can be efficient only when the position of inflection point is not subjected to possible sudden change. Full attentions should be paid to this unavoidable restriction imposed on any inelastic beam model.

Stiffness reduction properties under particular loading conditions with fixed inflection point are now examined. Table 1 gives the selected two loading conditions (plus the reference one) and the summarized characteristics of their end flexibilities and stiffness reduction ratios in the various beam models. Furthermore numerical values are given in Table 2, which were evaluated under typical inelasticity

Table 1 Stiffness Reduction Properties under Particular Loading Conditions with Fixed Position of Inflection Point

\begin{tabular}{|c|c|c|c|c|c|c|}
\hline & & & Composite Beam & One-Component & \multicolumn{2}{|c|}{ Author's Model } \\
\hline & & & Model & Model & parabola & parabola+delta \\
\hline \multirow{4}{*}[F]{$=\left[\begin{array}{ll}f_{11} & f_{12} \\
f_{21} & f_{2}\end{array}\right.$} & & \multirow{2}{*}{$f_{11}$} & \multirow{2}{*}{$\begin{array}{l}\frac{3}{2+g} f_{A}+\frac{(1-g)^{2}}{(1+2 g)(2+g} f_{B} \\
\quad\left(f_{o r} f_{A} \geq f_{B}\right) \\
\frac{2+g}{1+2 g} f_{A}\left(f_{o r} f_{A} \leq f_{B}\right)\end{array}$} & \multirow[t]{2}{*}{$f_{A}+\frac{1-g}{1+2 g} \cdot f_{0}$} & $\begin{array}{l}\frac{18+5 g}{9+10 g} \cdot f_{A}+\frac{3+5 g}{9+10 g} \cdot f_{B}-\frac{3+23 g+10 g^{2}}{(1+2 g)(9+10 g)} \cdot f_{0} \\
\quad F \frac{9+5 g}{9+10 \cdot g} \cdot \sqrt{\left(f_{A}-f_{0}\right)\left(f_{B}-f_{B}\right)}\end{array}$ & 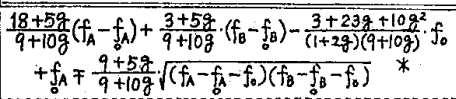 \\
\hline & & & & & $2 \cdot f_{A}+\frac{1}{3} \cdot f_{B}-\frac{1+1 i \cdot g}{3(1+2 g)} \cdot f_{D}=\sqrt{\left(f_{A}-f_{D}\right)\left(f_{B}-f_{D}\right)}$ & 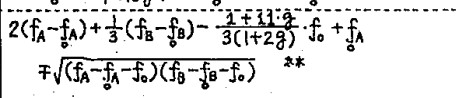 \\
\hline & $\left.f_{22}\right)$ & \multirow{2}{*}{$f_{12}$} & \multirow[t]{2}{*}{$\begin{array}{l}-\frac{1-g}{1+2 g} \cdot f_{B}\left(f_{\text {or }} f_{A} \geq f_{B}\right) \\
-\frac{1-g}{1+2 g} \cdot f_{A}\left(f_{o r} f_{A} \leq f_{B}\right)\end{array}$} & \multirow[t]{2}{*}{$-\frac{1-g}{1+2 g} \cdot f_{0}$} & $\begin{array}{c}-\frac{9-10 g}{2(9+10 g)}\left(f_{A}+f_{B}\right)+\frac{(7-10 g) g}{(1+2 g)(9+10 g)} \cdot f_{0} \\
\quad \pm \frac{6-5 g}{9+\log g} \sqrt{\left(f_{A}-f_{D}\right)\left(f_{B}-f_{D}\right)} *\end{array}$ & $\begin{array}{c}-\frac{9-10 g}{2(9+10 g)}\left(f_{A}+f_{B}-f_{A}-f_{B}\right)+\frac{(q-10 g) g}{(1+2 g)(9+10 g)} \cdot f_{0} \\
\quad \pm \frac{6-5 g}{q+10 g} \sqrt{\left(f_{A}-f_{A}-f_{B}\right)\left(f_{B}-f_{B}-f_{B}\right)}\end{array}$ \\
\hline & & & & & $-\frac{1}{2}\left(f_{A}+f_{A}\right)+\frac{3 g}{1+2 g} \cdot f_{0} \pm \frac{2}{3} \sqrt{\left(f_{A}-f_{0}\right)\left(f_{B}-f_{b}\right)} * * *$ & $\begin{array}{l}-\frac{1}{2}\left(f_{A}+f_{B}-f_{A}-f_{B}\right)+\frac{3 g}{1+2 g} \cdot f_{D} \\
\quad \pm \frac{2}{3} \sqrt{\left(f_{A}-f_{A}-f_{0}\right)\left(f_{B}-f_{B}-f_{B}\right)} * *\end{array}$ \\
\hline \multirow{2}{*}{$\begin{array}{l}\text { Loading } \\
\text { Type I. }\end{array}$} & \multirow{2}{*}{\multicolumn{2}{|c|}{\begin{tabular}{|c|} 
FLEXIBILITY \\
STIFFINESS \\
REDUCTION \\
RATIO \\
\end{tabular}}} & $f_{A}$ & $f_{\Lambda}$ & $f_{A}$ & $f_{A}$ \\
\hline & & & $\beta_{\mathrm{A}}$ & $\beta_{A}$ & $\beta_{A}$ & $\dot{\beta}_{A}$ \\
\hline \multirow{3}{*}{$\begin{array}{l}\text { Ioading } \\
\text { Type II }\end{array}$} & \multirow{2}{*}{\multicolumn{2}{|c|}{ FLEXIBILITY }} & \multirow{2}{*}{$\frac{3}{2+g} \cdot f_{A}+\frac{(1-g)^{2}}{(1+2 g)(2+g)} \cdot f_{0}$} & \multirow{2}{*}{$f_{A}+\frac{1-g}{1+2 g} \cdot f_{0}$} & $\frac{18+5 g}{9+10 g} \cdot f_{A}-\frac{12 \cdot g}{(1+2 g)(9+10 g)} \cdot f_{0} *$ & $\frac{18+5 g}{9+10} \cdot f_{A}-\frac{9-5 g}{9+10 g} \cdot f_{A}-\frac{12 g}{(1+2 g)(9+10 g g} \cdot f_{0}^{*}$ \\
\hline & & & & & $2 \cdot f_{A}-\frac{3 g}{1+2 g} \cdot f_{0}$ & $2 \cdot f_{A}-f_{A}-\frac{3 g}{1+2 g} \cdot f_{0}=K$ \\
\hline & \multicolumn{2}{|c|}{$\begin{array}{c}\text { S'IIFFIESSS } \\
\text { REDUTION } \\
\text { RATIO }\end{array}$} & $\begin{array}{c}\frac{(2+g)^{2}}{3(1+2 g)+(1-g)^{2} \cdot \beta_{A}} \cdot \beta_{A} \\
\simeq \frac{4}{3} \cdot \beta_{A}\end{array}$ & $\begin{array}{c}\frac{2+g}{(1+2 g)+(1-g) \cdot \beta_{A}} \cdot \beta_{A} \\
\simeq 2 \cdot \beta_{A}\end{array}$ & $\begin{array}{l}\frac{(9+10 g)(2+g)}{(1+2 g)(18+5 g)-12 g} \cdot \beta_{A} \cdot \beta_{A} \approx \beta_{A} * \\
\frac{2+g}{2(1+2 g)-3 g \cdot \beta_{A}} \cdot \beta_{A} \simeq \beta_{A} *{ }^{*}\end{array}$ & $\frac{(9+10 g)(2+g)}{\frac{(1+2 g)\left\{(18+5 g) \sim(9-5 g) \cdot \beta_{A}\left(\beta_{A}\right\}-12 g \cdot \beta_{A}\right.}{2+g} \beta_{A}^{*}} \frac{\beta^{*}}{(1+2 g)\left(2-\beta_{A} / \beta_{A}\right)-3 g \cdot \beta_{A}} \cdot \beta_{A}$ \\
\hline \multirow{3}{*}{$\begin{array}{l}\text { Loading } \\
\text { Type III }\end{array}$} & \multirow{2}{*}{\multicolumn{2}{|c|}{ FLEXIBILITY }} & \multirow{2}{*}{$\frac{3}{1+2 g} \cdot f_{A}$} & \multirow{2}{*}{$f_{A}+\frac{2(1-g)}{1+2 g} \cdot f_{0}$} & \multicolumn{2}{|c|}{$\frac{45}{q+\log } \cdot f_{A}-\frac{6(34)}{(1+2 g)(9+\log )} \cdot f_{0}$} \\
\hline & & & & & $5 \cdot f_{1}-\frac{2(1+5 g)}{1+2 g} \cdot f_{0}$ & \\
\hline & \multicolumn{2}{|c|}{$\begin{array}{l}\text { STIFFNESS } \\
\text { REDUCTION } \\
\text { RATIOO }\end{array}$} & $\beta_{A}$ & $\begin{array}{c}\frac{3}{(1+2 g)+2(1-g) \cdot \beta_{A}} \cdot \beta_{A} \\
\simeq 3 \cdot \beta_{A}\end{array}$ & $\begin{array}{c}\frac{9+10 g}{\sqrt{5(1+2 g)}-2(3+10 g) \cdot \beta_{1}} \\
\frac{3}{5(1+2 g)-2(1+5 g) \cdot}\end{array}$ & $\begin{array}{l}\beta_{A} \simeq \frac{3}{5} \cdot \beta_{A}^{*} \\
\beta_{A} \cdot \beta_{A} \simeq \frac{3}{5} \cdot \beta_{A}^{* *}\end{array}$ \\
\hline
\end{tabular}


Table 2 Numerical Comparison of Stiffness Reduction Properties (Table 1) for Trilinear Characteristics

\begin{tabular}{|c|c|c|c|c|c|c|c|c|c|c|c|c|}
\hline \multirow{3}{*}{\multicolumn{2}{|c|}{$\begin{array}{l}\text { STIFFNESS } \\
\text { REDUCTIONN } \\
\text { RATIO }\end{array}$}} & \multirow{3}{*}{$\begin{array}{c}\text { LOADIING } \\
\text { TYPE }\end{array}$} & \multicolumn{4}{|c|}{$E=0 \quad(a / D=\infty)^{t+1}$} & \multicolumn{6}{|c|}{$g=0.1(a / D \div 2, \text { for locding type } I)^{\dagger \dagger}$} \\
\hline & & & \multirow{2}{*}{$\begin{array}{l}\text { Composite } \\
\text { Beam :odel }\end{array}$} & \multirow{2}{*}{$\begin{array}{l}\text { One-Comp. } \\
\text { Model }\end{array}$} & \multicolumn{2}{|c|}{ Author's Model } & \multirow{2}{*}{$\begin{array}{l}\text { Composite } \\
\text { Beam Model }\end{array}$} & \multirow{2}{*}{$\begin{array}{l}\text { One-Comp. } \\
\text { Model. }\end{array}$} & \multicolumn{4}{|c|}{ Author's Model. } \\
\hline & & & & & parabola & rabola+delt & & & par & le & parabol & delta \\
\hline \multirow{2}{*}{ 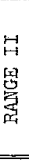 } & $\begin{array}{l}\beta_{A}=0.10 \\
\left(\beta_{A}=0\right)\end{array}$ & $\begin{array}{l}\text { I } \\
\text { II } \\
\text { II }\end{array}$ & $\begin{array}{l}0.2000 \\
0.1290 \\
0.1000 \\
\end{array}$ & $\begin{array}{l}0.1000 \\
0.1818 \\
0.2500 \\
\end{array}$ & & & $\begin{array}{l}0.1000 \\
0.1198 \\
0.1000\end{array}$ & $\begin{array}{l}0.1000 \\
0.1628 \\
0.2174\end{array}$ & & $\begin{array}{l}0.1000^{*} \\
0.0951 \\
0.0581 \\
\end{array}$ & $\begin{array}{l}0.1000^{* 1 *} \\
0.0886 \\
0.0526\end{array}$ & \\
\hline & $\begin{array}{l}\beta_{A}=0.15 \\
\left(\beta_{A}=0\right)\end{array}$ & $\begin{array}{l}\text { I } \\
\text { II } \\
\text { II }\end{array}$ & $\begin{array}{l}0.1500 \\
0.1905 \\
0.1500 \\
\end{array}$ & $\begin{array}{l}0.1500 \\
0.2609 \\
0.3462 \\
\end{array}$ & & & $\begin{array}{l}0.1500 \\
0.1778 \\
0.1500 \\
\end{array}$ & $\begin{array}{l}0.1500 \\
0.2360 \\
0.3061 \\
\end{array}$ & . & $\begin{array}{l}0.1500 \\
0.1431 \\
0.0893\end{array}$ & $\begin{array}{l}0.1500 \\
0.1338 \\
0.0811 \\
\end{array}$ & \\
\hline \multirow{4}{*}{ 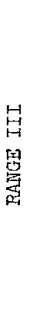 } & $\begin{array}{l}\beta_{A}=0.01 \\
\left(\beta_{A}=0.0111\right)\end{array}$ & $\begin{array}{l}\text { I } \\
\text { II } \\
\text { IIII }\end{array}$ & $\begin{array}{l}0.0100 \\
0.0133 \\
0.0100 \\
\end{array}$ & $\begin{array}{l}0.0100 \\
0.0198 \\
0.0294\end{array}$ & $\begin{array}{l}0.0100 \\
0.0100 \\
0.0060\end{array}$ & $\begin{array}{l}0.0100 \\
0.0182 \\
0.0060 \\
\end{array}$ & $\begin{array}{l}0.0100 \\
0.0122 \\
0.0100\end{array}$ & $\begin{array}{l}0.01 .00 \\
0.0174 \\
0.0246 \\
\end{array}$ & $\begin{array}{l}0.0200^{*} \\
0.0095 \\
0.0056\end{array}$ & $\begin{array}{l}0.0100 \text { * } \\
0.0088 \\
0.0050 \\
\end{array}$ & $\begin{array}{l}0.0100^{*} \\
0.0162 \\
0.0056\end{array}$ & $\begin{array}{l}0.0100^{\text {Wh }} \\
0.0160 \\
0.0050\end{array}$ \\
\hline & $\mid \begin{array}{l}\beta_{A}=0.001 \\
\left(\beta_{A}=0.0010\right)\end{array}$ & II & $\begin{array}{l}0.0010 \\
0.0013 \\
0.0010 \\
\end{array}$ & $\begin{array}{l}0.0010 \\
0.0020 \\
0.0030 \\
\end{array}$ & $\begin{array}{l}0.0010 \\
0.0010 \\
0.0006\end{array}$ & $\begin{array}{l}0.0010 \\
0.0020 \\
0.0006\end{array}$ & $\begin{array}{l}0.0010 \\
0.0012 \\
0.0010\end{array}$ & $\begin{array}{l}0.0010 \\
0.0017 \\
0.0025\end{array}$ & $\begin{array}{l}0.0010 \\
0.0009 \\
0.0006\end{array}$ & $\begin{array}{l}0.0010 \\
0.0009 \\
0.0005\end{array}$ & $\begin{array}{l}0.0010 \\
0.0018 \\
0.0006\end{array}$ & $\begin{array}{l}0.0010 \\
0.0018 \\
0.0005 \\
\end{array}$ \\
\hline & $\begin{array}{l}\beta_{A}=-0.05 \\
\left(\beta_{A}=-0.0476\right)\end{array}$ & II & $\begin{array}{l}-0.0500 \\
-0.0678 \\
-0.0500\end{array}$ & $\begin{array}{l}-0.0500 \\
-0.1053 \\
-0.1667\end{array}$ & $\begin{array}{l}- \\
-\end{array}$ & $\begin{array}{l}-0.0500 \\
-0.1053 \\
-0.0294\end{array}$ & $\begin{array}{l}-0.0500 \\
-0.0619 \\
-0.0500\end{array}$ & $\begin{array}{l}-0.0500 \\
-0.0909 \\
-0.1351\end{array}$ & $\therefore$ & - & $\begin{array}{l}-0.0500 \\
-0.0909 \\
-0.0272 \\
\end{array}$ & $\begin{array}{l}-0.0500 \\
-0.0909 \\
-0.0244\end{array}$ \\
\hline & $\left|\begin{array}{l}\beta_{A}=-0.10 \\
\left(\beta_{A}=-0.0909\right)\end{array}\right|$ & $\begin{array}{l}\text { I } \\
\text { II }\end{array}$ & $\begin{array}{l}-0.1000 \\
-0.1379 \\
-0.2000\end{array}$ & $\begin{array}{l}-0.1000 \\
-0.2222 \\
-0.3750\end{array}$ & $\bar{z}$ & $\begin{array}{l}-0.1000 \\
-0.2222 \\
-0.0577\end{array}$ & $\begin{array}{l}-0.1000 \\
-0.1253 \\
-0.1000\end{array}$ & $\begin{array}{l}-0.1000 \\
-0.1892 \\
-0.2941\end{array}$ & $\bar{z}$ & $\begin{array}{l}- \\
-\end{array}$ & $\begin{array}{l}-0.1000 \\
-0.1892 \\
-0.0532\end{array}$ & $\begin{array}{l}-0.1000 \\
-0.1892 \\
-0.0476\end{array}$ \\
\hline
\end{tabular}

parameters in trilinear characteristics idealization of $\mathrm{R} / \mathrm{C}$ members.

The author cannot give any definite comment to these results, since experimental data, suitable for discussing the validity of beam modeling from the above results, are unfortunately very poor at present. However, the following general relationships among stiffness reduction ratios in Loading Typs I, II, III are worthy of special note.

For $g=0$,

$$
\begin{array}{lll}
\mathrm{I}=\mathrm{III}<\mathrm{II} & (\mathrm{II} \fallingdotseq(4 / 3) \cdot \mathrm{I}) & \text { for Composite Beam Model } \\
\mathrm{I}<\mathrm{II}<\mathrm{II} & (\mathrm{I}: \mathrm{II}: \mathrm{II} \fallingdotseq 1: 2: 3) & \text { for One-Component Model } \\
\mathrm{I}=\mathrm{II}>\mathrm{III} & (\mathrm{III} \fallingdotseq(3 / 5) \cdot \mathrm{I}) & \text { for the Author's Model }
\end{array}
$$

This definite difference could lead to a tentative conclusion on the inappropriateness of several modeling techniques treated herein.

\section{INFLUENCE OF INITIAL STRESS DUE TO DEAD AND LIVE LOADS}

The preceding discussions on inelastic beam modeling have been developed under the linear distribution of bending moment along member axis. This is not the case with girder elements, particularly when the initial bending moment due to dead and live loads are too large to disregard its effect as compared to the bending moment due to earthquake exitation. Stated in another way, the foregoing formulation of inelastic beam model need be modified, when the instantaneous distribution of combined

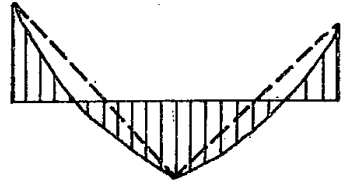

INITIAL BENDING MOMENT DISTRIBUTION DUE TO DEAD AND LIVE LOADS

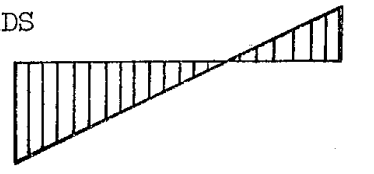

BENDING MOMENT DISTRIBUTION DUE TO EARTHQUAKE DISTURBAIYCF

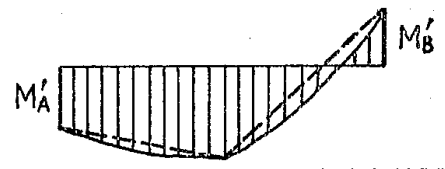

INSTANTANEOUS BENDING MOMENT DISTRIBUTION DURING EARTHQUAKE

Fig. 12 Instantaneous Bending Moment Distribution of Girder

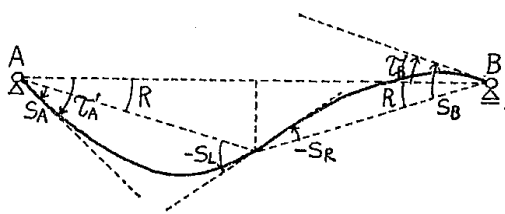

Fig. 13-a Deform-ed Configuration

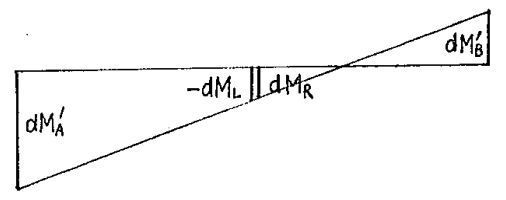

Fig. 13-b Incremental Bending Moment Distribution

Fig. 13 Deformation and Incremental Stress of Girder Element 
large bending moment due to dead and live loads and earthquake disturbance is far from approximately linear along member axis (Fig. 12). The following is an attempt to take this influence of initial stress into consideration, under simplification of the problem that the instantaneous distribution shape of total bending moment can be well replaced by the broken line shown in Fig. 12.

From the deform-ed configuration displayed in Fig. 13-a, the continuity requirement of the rotation at mid- span point leads to

$$
\left\{\begin{array}{l}
d \tau_{A^{\prime}} \\
d \tau_{B^{\prime}}
\end{array}\right\}=\left[E_{L}\right]\left\{\begin{array}{l}
d s_{A} \\
d s_{L}
\end{array}\right\}+\left[E_{R}\right]\left\{\begin{array}{l}
d s_{R} \\
d s_{B}
\end{array}\right\} \quad \text { with } \quad\left[E_{L}\right]=\left[\begin{array}{cc}
1, & -1 / 2 \\
0, & 1 / 2
\end{array}\right] \quad\left[E_{R}\right]=\left[\begin{array}{cc}
1 / 2, & 0 \\
-1 / 2, & 1
\end{array}\right]
$$

On the other hand, the incremental relations among the bending moments given in Fig. 13-b are

$$
\left\{\begin{array}{l}
d M_{A}{ }^{\prime} \\
d M_{L}
\end{array}\right\}=\left[E_{L}\right]^{T}\left\{\begin{array}{l}
d M_{A^{\prime}} \\
d M_{B^{\prime}}
\end{array}\right\},\left\{\begin{array}{l}
d M_{R} \\
d M_{B}^{\prime}
\end{array}\right\}=\left[E_{R}\right]^{T}\left\{\begin{array}{l}
d M_{A^{\prime}} \\
d M_{B^{\prime}}
\end{array}\right\}
$$

Then, representing the flexibility relations of the left and right beam elements by

$$
\left\{\begin{array}{l}
d s_{A} \\
d s_{L}
\end{array}\right\}=\left[F_{L}\right]\left\{\begin{array}{l}
d M_{A}^{\prime} \\
d M_{L}
\end{array}\right\},\left\{\begin{array}{l}
d s_{R} \\
d s_{B}
\end{array}\right\}=\left[F_{R}\right]\left\{\begin{array}{l}
d M_{R} \\
d M_{B}^{\prime}
\end{array}\right\}
$$

respectively, the following relation is obtained for the combined beam element.

$$
\begin{aligned}
& \left\{\begin{array}{l}
d \tau_{A^{\prime}} \\
d \tau_{B^{\prime}}
\end{array}\right\}=\left[F^{\prime}\right]\left\{\begin{array}{l}
d M_{A}{ }^{\prime} \\
d M_{B^{\prime}}
\end{array}\right\} \\
& {\left[F^{\prime}\right]=\left[E_{L}\right]^{T}\left[F_{L}\right]\left[E_{L}\right]+\left[E_{R}\right]^{T}\left[F_{R}\right]\left[E_{R}\right]}
\end{aligned}
$$

This flexibility matrix $\left[F^{\prime}\right]$ will be evaluated at each inelasticity stage by respective evaluations of $\left[F_{L}\right]$ and $\left[F_{R}\right]$, tracing the three relations $f_{A}=d \tilde{\tau}_{A}{ }^{\prime} / d M_{A^{\prime}}, f_{B}=d \tilde{\tau}_{B}{ }^{\prime} / d M_{B}{ }^{\prime}$ and $f_{M}=d \tilde{\tau}_{M} / d M_{M}$. Note the relaionships $d M_{M}=\left(d M_{A^{\prime}}-d M_{B}{ }^{\prime}\right) / 2$ and $M_{L}=-M_{M}, M_{R}=+M_{M}$.

\section{TIME-DEPENDENCE OF INELASTIC CHARACTERISTICS DUE TO FLUCTUATION OF}

\section{AXIAL FORCE}

The foregoing treatments on inelastic behavior of a beam element have been restricted to a simplified case, the additionally acting axial force being time-invariant. However, actual inelastic member properties are dependent not only on hysteretic histories of the applied bending moments but also on fluctuation of the existing axial force. This influence will be not so significant in most cases, but it may not be negligibly small. In case of trilinear idealization of column characteristics, for instance, inelasticity parameters $M_{y}, M_{c}$ and $\alpha_{y}$ depend on the axial force at each instant, and are expected to vary according to its fluctuation. Fig. 14 shows this matter schematically; viz., the skeleton curve for $M^{\prime} \sim \tilde{\tau}^{\prime}$ relation changes from the one indicated by full line to the one by broken line, accompanying the increase of axial compression.

An attempt to take the current effect into main consideration was reported in Ref. 29 for static analysis of R/C structures, however the

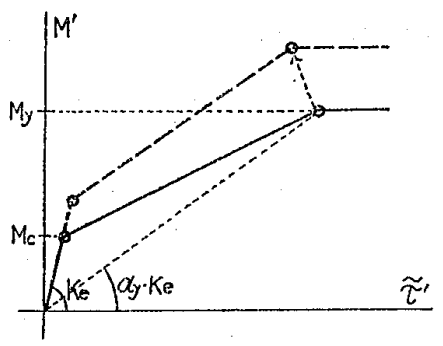

Fig. 14 Moving Skeleton Curve technique available at present for this purpose is not satisfactory. In the following, the usual case is treated where the fluctuation of axial force yields merely secondary effect upon member characteristics, in comparison with the primary effect due to bending moments.

In modifying stiffness formulation of beam element taking into account the above dependence of inelastic characteristics on the axial force, the quantities $M_{A^{\prime}}, M_{B}{ }^{\prime}$ and $N_{A B}$ are regarded to be functions of thefollowing arguments, respectively.

$$
\begin{aligned}
& M_{A}{ }^{\prime}=M_{A^{\prime}}\left(\tau_{A^{\prime}}, \tau_{B^{\prime}}, N_{A B}\right) \\
& M_{B^{\prime}}=M_{B^{\prime}}\left(\tau_{A^{\prime}}, \tau_{B^{\prime}}, N_{A B}\right) \\
& N_{A B}=N_{A B}\left(\tau_{A^{\prime}}, \tau_{B^{\prime}}, \varepsilon_{A B}\right)
\end{aligned}
$$

Then the incremental representation of these relations and the requirement of symmetry of the matrix lead to the following formulation of the stiffness matrix. 


$$
\left\{\begin{array}{l}
d M_{A^{\prime}} \\
d M_{B}{ }^{\prime} \\
d N_{A B}
\end{array}\right\}=\left(\left[K_{0}\right]+K_{\varepsilon}\left[K_{1}\right]\right)\left\{\begin{array}{l}
d \tau_{A^{\prime}} \\
d \tau_{B^{\prime}} \\
d \varepsilon_{A B}
\end{array}\right\}
$$

where

$$
\begin{aligned}
& {\left[K_{0}\right]=\left[\begin{array}{ccc}
\partial M_{A^{\prime}} / \partial \tau_{A^{\prime}}, & \partial M_{A^{\prime}} / \partial \tau_{B^{\prime}}, & 0 \\
\partial M_{B}^{\prime} / \partial \tau_{A^{\prime}}, & \partial M_{B}^{\prime} / \partial \tau_{B^{\prime}}, & 0 \\
0, & 0, & K_{\varepsilon}
\end{array}\right]} \\
& \text { : ordinary instantaneous stiffness matrix neglecting the inelastic stiffness } \\
& \text { coupling between bending moments and axial force. } \\
& K_{\varepsilon}=\partial N_{A B} / \partial \varepsilon_{A B} \quad: \text { instantaneous axial stiffness. } \\
& {\left[K_{1}\right]=\left[\begin{array}{ccc}
\mu_{A}^{2}, & \mu_{A} \mu_{B}, & \mu_{A} \\
\mu_{A} \mu_{B}, & \mu_{B}{ }^{2}, & \mu_{B} \\
\mu_{A}, & \mu_{B}, & 0
\end{array}\right] \quad\left(\mu_{A}=\partial M_{A^{\prime}} / \partial N_{A B}, \mu_{B}=\partial M_{B}{ }^{\prime} \partial N_{A B}\right)}
\end{aligned}
$$

Besides the matrix $\left[K_{0}\right]$ which is estimated through the technique already mentioned, this modified formulation requires two inelasticity parameters $\mu_{A}$ and $\mu_{B}$ to be evaluated at each loading stage.

In general, consideration of such effect has significance only for outer columns of a slender building. Even in these cases, however, the effect on overall structural behavior will be generally canceled each other, because of entirely converse actions at both sides of building.

\section{MECHANICS OF BEAM-COLUMN CONNECTION AND DESCRIPTIONS OF MEMBER CHARACTERISTICS FROM PANEL POINT LEVEL}

Girders, columns and shear walls are combined at beam to column connections by displacement compatibility requirements. In this section, some remarks are mentioned, first on mechanical idealization of this element, mainly focused on the meaning of panel distortional moment, and then on how to describe member characteristics of girders, columns and shear walls in terms of the forces and displacements defined at panel points.

Beam to column connection is usually idealized by a panel deformable due to existing shear stress only, and its displacement field is treated to consist of combined rigid-body displacements and shear strain uniformly distributed in the panel. Concerning the gross nature of the influence of this shear deformation on overall structural behavior, complete discussions were presented by $\mathrm{H}$. Umemura et al. ${ }^{38), 6)}$

The geometry of shear panel and its displacement mode with four degrees of freedom (horizontal and vertical translations, rotation, and shear distortion) are shown in Fig. 15-a and -b, respectively. Generalized forces associated with these four generalized displacements can be derived by establishing the equations governing the behavior of shear panel from energy approach. Through this derivation procedure, it is intended to introduce the concept of 'panel distortional moment' in a definite way, and to clarify its mechanical meaning which has been rather ambiguous. ${ }^{399,5)}$

Denoting the horizontal and vertical translational displacements of the panel centroid, and the rotational and distortional angles of the panel, by $u, v, \theta$ and $r$, respectively, the displacement of each

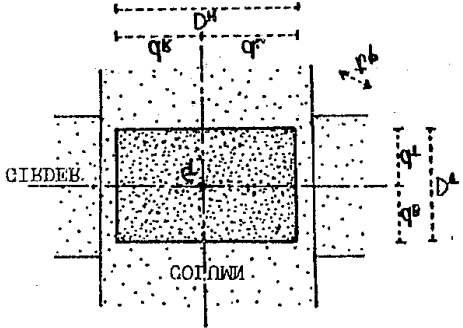

Fig. 15-a Geometry of Shear Panel

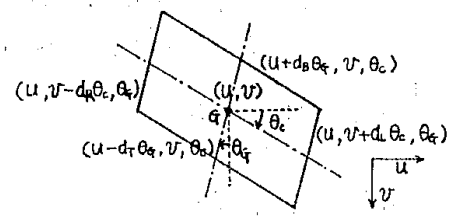

Fig. 15-b Displacement Mode of Shear Panel

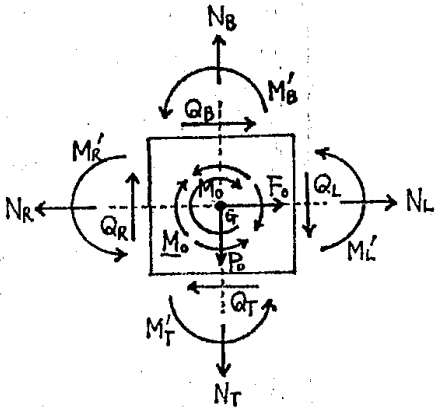

Fig. 15-c Internal Forces from Adjacent Members and External Forces Acting on Shear Panel

Fig. 15 Beam to Column Connection 
boundary side of the panel is determined as Fig. 15-b shows

$\theta_{C}=\theta+r / 2$ : rotation of boundary side adjacent to column

$\theta_{G}=\theta-r / 2$ : rotation of boundary side adjacent to girder

The incremental work $d W_{e}$ done by internal forces from adjacent members and external forces acting on the shear panel (Fig. 15-c) is expressed by

$$
\begin{aligned}
d W_{e}= & \left(-Q_{T} \cdot d\left(u-d_{T} \theta_{G}\right)+N_{T} d v-M_{T}^{\prime} d \theta_{C}\right)+\left(Q_{B} \cdot d\left(u+d_{B} \theta_{G}\right)-N_{B} d v-M_{B}^{\prime} d \theta_{C}\right) \\
& +\left(N_{L} d u+Q_{L} \cdot d\left(v+d_{L} \theta_{C}\right)-M_{L}^{\prime} d \theta_{G}\right)+\left(-N_{R} d u-Q_{R} \cdot d\left(v-d_{R} \theta_{C}\right)-M_{R^{\prime}} d \theta_{G}\right) \\
& +\left(F_{0} \cdot d u+P_{0} \cdot d v+M_{0} \cdot d \theta+M_{0} \cdot d \gamma\right)
\end{aligned}
$$

where $N_{T}, N_{B}, N_{L}, N_{R}$ : internal axial forces

$Q_{T}, Q_{B}, Q_{L}, Q_{R}$ : internal shear forces

$M_{T}{ }^{\prime}, M_{B}{ }^{\prime}, M_{L}{ }^{\prime} M_{R^{\prime}}$ : internal bending moments

$F_{0}$ : external horizontal force

$P_{0}$ : external vertical force

$M_{0}$ : external rotational moment

$\boldsymbol{M}_{0}$ : external distortional moment

And, the associated increment of shear strain energy $d W_{i}$ of the panel is

$d W_{i}=V_{p} \cdot \tau_{p} \cdot d \gamma$

where $V_{p}=t_{p} \cdot D_{H} D_{V}$ : panel volume

$\tau_{p}:$ stress in the constant shear strain field

Application of the equilibrium requirement $d W_{e}=d W_{i}$ yields

and therefore

$$
\begin{aligned}
& \left(N_{L}-N_{R}-Q_{T}+Q_{B}+F_{0}\right) d u+\left(N_{T}-N_{B}+Q_{L}-Q_{R}+P_{0}\right) d v \\
& \quad+\left(+d_{T} Q_{T}+d_{B} Q_{B}+d_{L} Q_{L}+d_{R} Q_{R}-M_{T}^{\prime}-M_{B}{ }^{\prime}-M_{L}^{\prime}-M_{R}{ }^{\prime}+M_{0}\right) d \theta \\
& \quad+\left(\left(-d_{T} Q_{T}-d_{B} Q_{B}+d_{L} Q_{L}+d_{R} Q_{R}-M_{T}^{\prime}-M_{B}+M_{L}^{\prime}+M_{R}^{\prime}\right) / 2+M_{0}-V_{p} \cdot \tau_{p}\right) d r=0
\end{aligned}
$$

$$
\begin{aligned}
& F_{i}=F_{0} \quad d F_{i}=d F_{0} \\
& P_{i}=P_{0} \quad \text { or } \quad d P_{i}=d P_{0} \\
& M_{i}=M_{0} \quad \text { or } \quad d M_{i}=d M_{0} \\
& \boldsymbol{M}_{\boldsymbol{i}}+V_{\boldsymbol{p}} \cdot \tau_{p}=\boldsymbol{M}_{0} \quad d \boldsymbol{M}_{i}+K_{p} \cdot d \gamma=d \boldsymbol{M}_{0} \\
& \text { where } K_{p}=G V_{p} \text { : defined as 'panel stiffness' } \\
& G \text { : instantaneous shear modulus }
\end{aligned}
$$

under the definition of generalized internal forces $F_{i}, P_{i}, M_{i}$ and $\boldsymbol{M}_{\boldsymbol{i}}$

$F_{i}=-N_{L}+N_{R}+Q_{T}-Q_{B}:$ internal horizontal force

$P_{i}=-N_{T}+N_{B}-Q_{L}+Q_{R}$ : internal vertical force

$M_{i}=-d_{T} Q_{T}-d_{B} Q_{B}-d_{L} Q_{L}-d_{R} Q_{R}+M_{T}{ }^{\prime}+M_{B}{ }^{\prime}+M_{L}{ }^{\prime}+M_{R}{ }^{\prime}$ : internal rotational moment

$\boldsymbol{M}_{i}=\left(+d_{T} Q_{T}+d_{B} Q_{B}-d_{L} Q_{L}-d_{R} Q_{R}+M_{T}{ }^{\prime}+M_{B}{ }^{\prime}-M_{L}{ }^{\prime}-M_{R}{ }^{\prime}\right) / 2$ : internal distortional moment

A resolution process of acting forces on beam-columin connection shown in Fig. 16 facilitates one to understand the meaning of panel distortional moment intuitively and more definitely.

$$
\begin{aligned}
& \left\{\begin{array}{l}
F=+N_{L}-N_{R}-Q_{T}+Q_{B}+F_{0}: \text { resultant horizontal force } \\
P=+N_{T}-N_{B}+Q_{L}-Q_{R}+P_{0}: \text { resultant vertical force } \\
\hat{Q}_{H}=\left(+d_{T} Q_{T}+d_{B} Q_{B}-M_{L}^{\prime}-M_{R}^{\prime}\right) / D_{V}+\hat{Q}_{H 0}: \text { resultant horizontal coupling force } \\
\hat{Q}_{V}=\left(+d_{L} Q_{L}+d_{R} Q_{R}-M_{T}^{\prime}-M_{B}^{\prime}\right) / D_{H}+\hat{Q}_{V 0}: \text { resultant vertical coupling force }
\end{array}\right. \\
& \left\{\begin{array}{l}
\hat{Q}_{H_{0}}=\left(\frac{1}{2} M_{0}-M_{0}\right) / D_{V} \\
\hat{Q}_{V 0}=\left(\frac{1}{2} M_{0}+M_{0}\right) / D_{H}
\end{array}\right. \\
& \left\{\begin{array}{l}
M=D_{H} \hat{Q}_{V}+D_{V} \hat{Q}_{H}=d_{T} Q_{T}+d_{B} Q_{B}+d_{L} Q_{L}+d_{R} Q_{R}-M_{T^{\prime}}-M_{B}^{\prime}-M_{L}^{\prime}-M_{R}^{\prime}+M_{0} \\
\quad: \text { resultant rotational moment } \\
\boldsymbol{M}=\left(D_{H} \hat{Q}_{V}-D_{V} \hat{Q}_{H}\right) / 2=\left(-d_{T} Q_{T}-d_{B} Q_{B}+d_{L} Q_{L}+d_{R} Q_{R}-M_{T}^{\prime}-M_{B}^{\prime}+M_{L}^{\prime}+M_{R}\right) / 2+M_{0}
\end{array}\right.
\end{aligned}
$$

: resultant distortional moment 
The resolution of coupling forces $\hat{Q}_{H}$ and $\hat{Q}_{V}$ into the rotational and the distortional moments $M$ and $M$ at the stages IV, VII, Vill in this figure, implies that the panel distortional moment is understood as the deviatoric component of the acting moments, which yields shear deformation, while the other forces and moment are related to the displacements as a rigid body. Viz,,

horizontal shear stress

$$
\tau_{H}=\left(\frac{\boldsymbol{M}}{D_{V}}\right) /\left(t_{p} D_{H}\right)=\boldsymbol{M} / V_{p}
$$

vertical shear stress

$$
\begin{gathered}
\tau_{V}=\left(\frac{\boldsymbol{M}}{D_{H}}\right) /\left(t_{p} D_{V}\right)=\boldsymbol{M} / V_{p} \\
\tau_{H}=\tau_{V}\left(=\tau_{p}\right) ; d \tau_{p}=G d r \text { or } d \boldsymbol{M}=K_{p} d r
\end{gathered}
$$

On the basis of the on above introduction of generalized forces of the panel point contributed from the adjacent members, the stiffness matrices of girder, column and shear wall members, which were expressed in terms of local forces and deformations defined atr espective members, are then converted into the stiffness matrices rewritten in terms of the relationbetween generalized forces

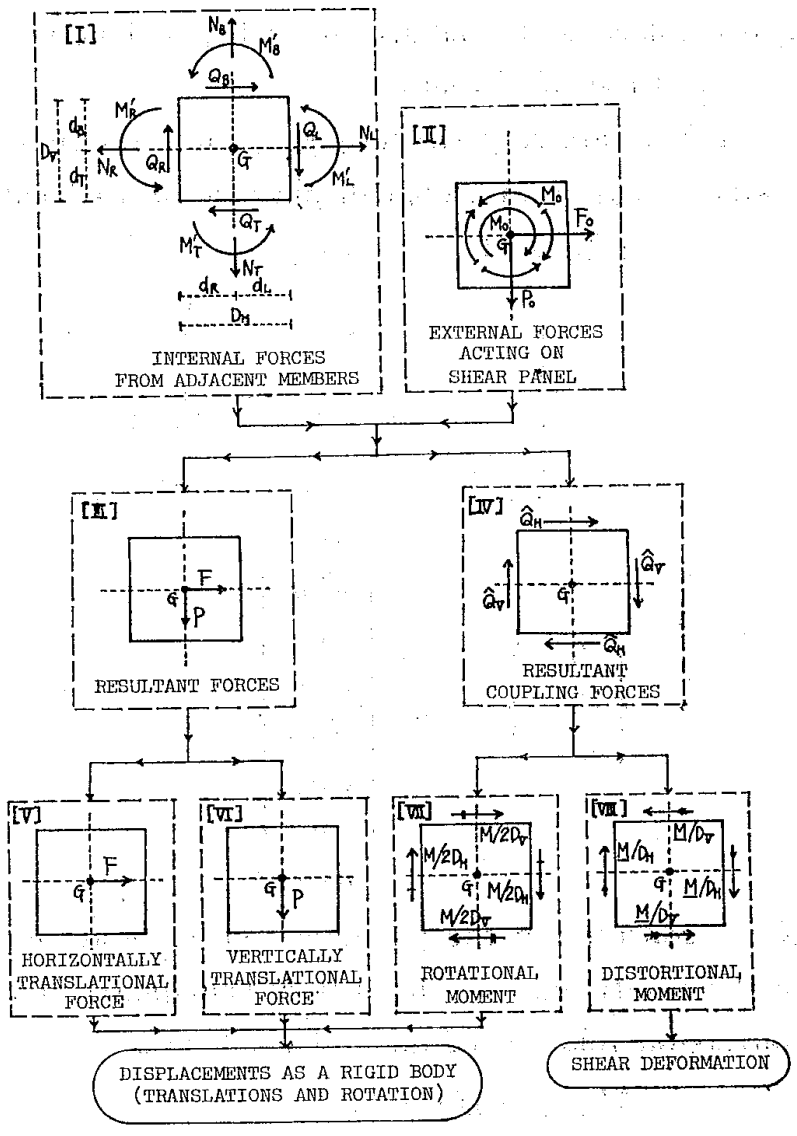

Fig. 16 Resolution of Forces Acting on Beam-Column Connection
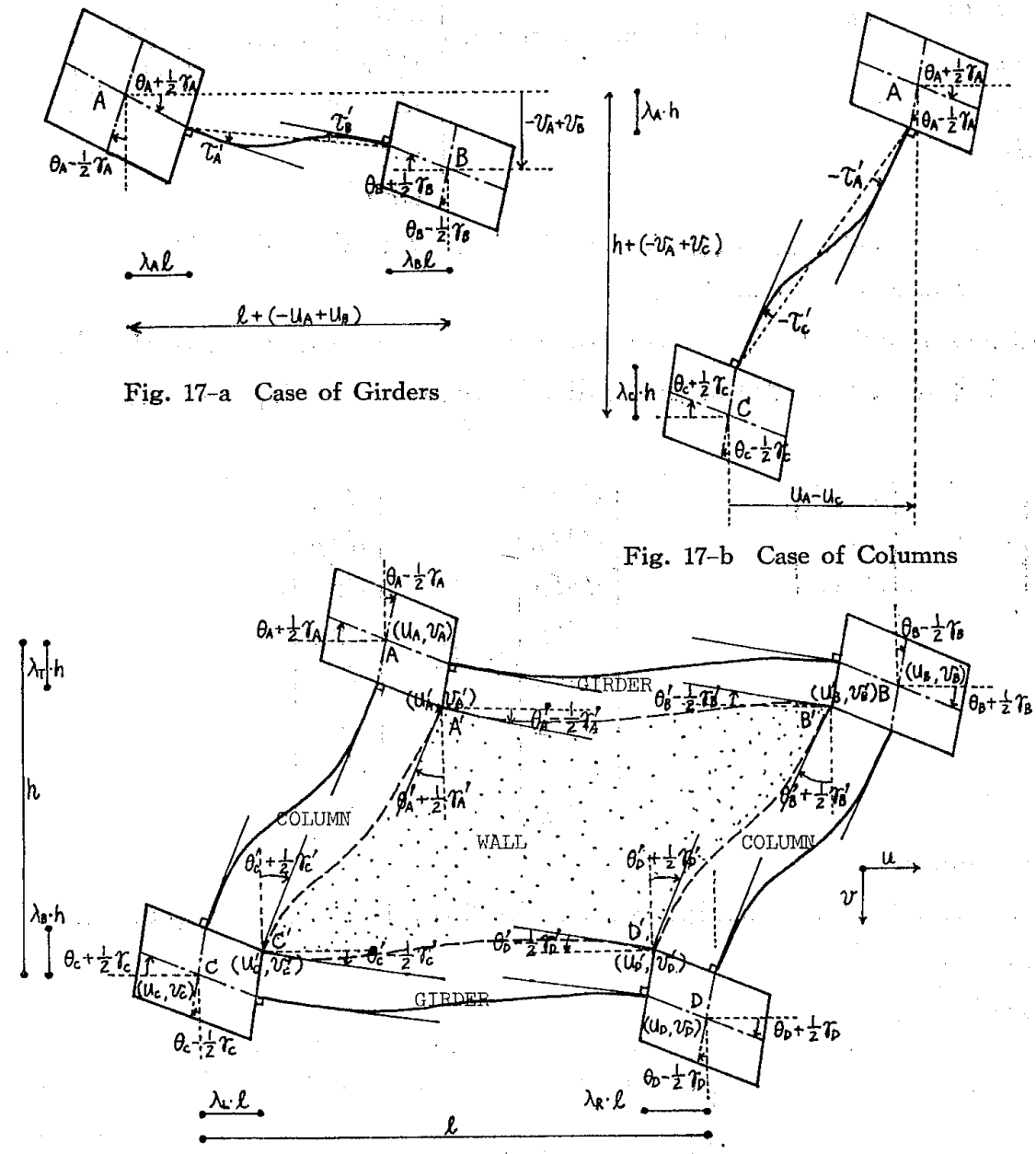

Fig. 17-c Case of Shear Walls

Fig. 17 Deform-ed Configuration of Elements 
and displacements defined at each panel point.

a) Case of Girders

First, referring to the geometrical relationships shown in Fig. 17-a, the displacement conversion matrix $\left[A_{G}\right]$ from global displacements to local ones of girder element is given by

$$
\begin{aligned}
& {\left[A_{G}\right]=\left(1-\lambda_{A}-\lambda_{B}\right)^{-1}}
\end{aligned}
$$

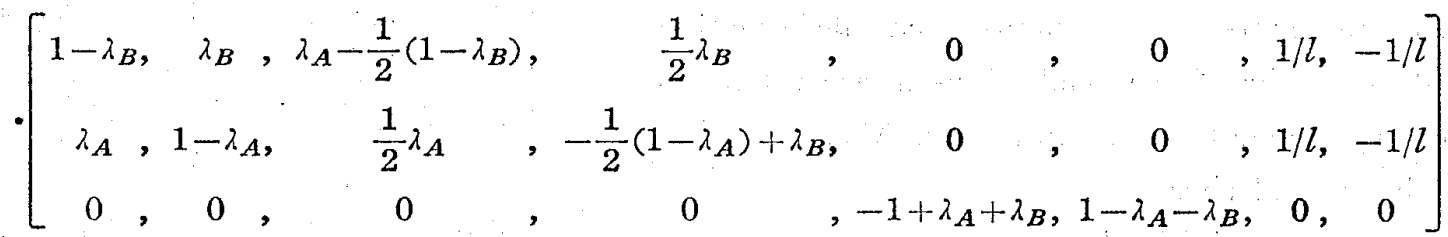

$$
\begin{aligned}
& \left\{\begin{array}{l}
d \tau_{A^{\prime}} \\
d \tau_{B^{\prime}} \\
d \varepsilon_{A B}
\end{array}\right\}=\left[A_{G}\right]\left\{\begin{array}{l}
d \theta_{A} \\
d \theta_{B} \\
d r_{A} \\
d r_{B} \\
d u_{A} \\
d u_{B} \\
d v_{A} \\
d v_{B}
\end{array}\right\}
\end{aligned}
$$

Next, considering the participation of end moments, shear and axial force of this girder element to the rotational and the distortional panel moments and the translational panel forces, the associated conversion relation of generalized forces is

$$
\begin{aligned}
& M_{A}=-d_{L} Q_{L}+M_{L}^{\prime} \\
& M_{B}=-d_{R} Q_{R}+M_{R^{\prime}} \\
& M_{A}=\left(-d_{L} Q_{L}-M_{L}^{\prime}\right) / 2 \\
& M_{B}=\left(-d_{R} Q_{R}-M_{R^{\prime}}\right) / 2 \\
& F_{A}=-N_{L} \\
& \text { or in matrix form, }\left\{\begin{array}{l}
d M_{A} \\
d M_{B} \\
d M_{A} \\
d M_{B} \\
d F_{A} \\
d F_{B} \\
d P_{A} \\
d P_{B}
\end{array}\right\}=\left[A_{G}\right]^{T}\left\{\begin{array}{l}
d M_{A}^{\prime} \\
d M_{B}{ }^{\prime} \\
d N_{A B}
\end{array}\right\} \\
& F_{B}=+N_{R} \\
& P_{A}=-Q_{L} \\
& P_{B}=+Q_{R}
\end{aligned}
$$

where $M_{L}^{\prime}=M_{A^{\prime}}, M_{R^{\prime}}=M_{B}{ }^{\prime} ; Q_{L}=Q_{R}=\left(-M_{A^{\prime}}-M_{B}{ }^{\prime}\right) / l^{\prime} ; N_{L}=N_{R}=N_{A B}$;

$$
d_{L}=\lambda_{A} \cdot l, \quad d_{R}=\lambda_{B} \cdot l ; \quad l^{\prime}=\left(1-\lambda_{A}-\lambda_{B}\right) \cdot l
$$

Then the local stiffness matrix $[K]$ of the girder is transformed into the global stiffness matrix $\left[B_{G}\right]=\left[A_{G}\right]^{T}\left[K_{G}\right]\left[A_{G}\right]$ in terms of the generalized forces and displacements of panel point, under the next notations.

$$
\left\{\begin{array}{l}
d M_{A^{\prime}} \\
d M_{B^{\prime}} \\
d N_{A B}
\end{array}\right\}=\left[K_{G}\right]\left\{\begin{array}{l}
d \tau_{A}{ }^{\prime} \\
d \tau_{B^{\prime}} \\
d \varepsilon_{A B}
\end{array}\right\} \quad\left\{\begin{array}{l}
d M_{A} \\
d M_{B} \\
d M_{A} \\
d M_{B} \\
d F_{A} \\
d F_{B} \\
d P_{A} \\
d P_{B}
\end{array}\right)=\left[B_{G}\right] \cdot\left(\begin{array}{l}
d \theta_{A} \\
d \theta_{B} \\
d r_{A} \\
d r_{B} \\
d u_{A} \\
d u_{B} \\
d v_{A} \\
d v_{B}
\end{array}\right\}
$$

b) Case of Columns

Referring to geometrical relationships shown in Fig. 17-b, the displacement conversion matrix $\left[A_{C}\right]$ in this instance is

$$
\begin{aligned}
& {\left[A_{C}\right]=\left(1-\lambda_{A}-\lambda_{C}\right)^{-1}}
\end{aligned}
$$

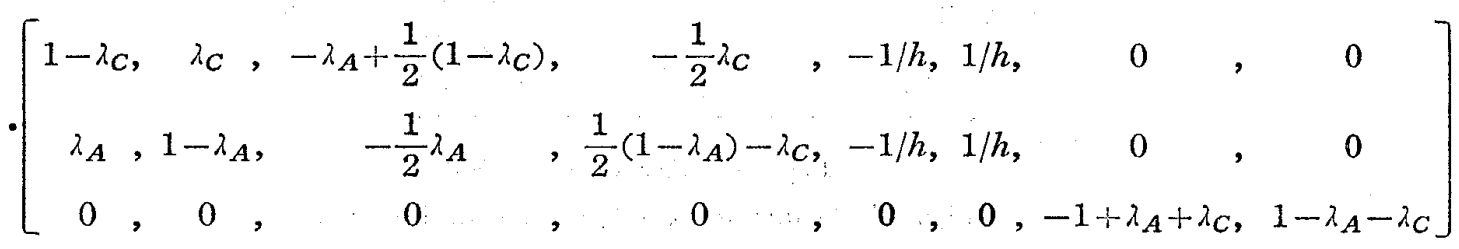




$$
\left\{\begin{array}{l}
d \tau_{A^{\prime}} \\
d \tau_{C^{\prime}} \\
d \varepsilon_{A C}
\end{array}\right\}=\left[A_{C}\right]\left\{\begin{array}{l}
d \theta_{A} \\
d \theta_{C} \\
d \tau_{A} \\
d r_{C} \\
d u_{A} \\
d u_{C} \\
d v_{A} \\
d v_{C}
\end{array}\right\}
$$

and the associated conversion relation of generalized forces is

$$
\begin{aligned}
& M_{A}=-d_{T} Q_{T}+M_{T}{ }^{\prime} \\
& M_{C}=-d_{B} Q_{B}+M_{B}{ }^{\prime} \\
& \boldsymbol{M}_{A}=\left(+d_{T} Q_{T}+M_{T^{\prime}}\right) / 2 \\
& \boldsymbol{M}_{C}=\left(+d_{B} Q_{B}+M_{B}^{\prime}\right) / 2 \\
& F_{A}=+Q_{T} \\
& \text { or in matrix form, } \\
& \left\{\begin{array}{l}
d M_{A} \\
d M_{C} \\
d \boldsymbol{M}_{A} \\
d M_{C} \\
d F_{A} \\
d F_{C} \\
d P_{A} \\
d P_{C}
\end{array}\right\}=\left[A_{C}\right]^{T}\left\{\begin{array}{l}
d M_{A^{\prime}} \\
d M_{C}{ }^{\prime} \\
d N_{A C}
\end{array}\right\}
\end{aligned}
$$

where $\quad M_{T}^{\prime}=M_{A^{\prime}} ; M_{B}^{\prime}=M_{C}{ }^{\prime} ; Q_{T}=Q_{B}=\left(-M_{A^{\prime}}-M_{C}{ }^{\prime}\right) / h^{\prime} ; N_{T}=N_{B}=N_{A C} ;$

$$
d_{T}=\lambda_{A} \cdot h, \quad d_{B}=\lambda_{C} \cdot h ; \quad h^{\prime}=\left(1-\lambda_{A}-\lambda_{C}\right) \cdot h
$$

Then the global stiffness matrix is given by $\left[B_{C}\right]=\left[A_{C}\right]^{T}\left[K_{C}\right]\left[A_{C}\right]$, where

$$
\left\{\begin{array}{l}
d M_{A^{\prime}} \\
d M_{C^{\prime}} \\
d N_{A C}
\end{array}\right\}=\left[K_{C}\right]\left\{\begin{array}{l}
d \tau_{A^{\prime}} \\
d \tau_{C^{\prime}} \\
d \varepsilon_{A C}
\end{array}\right\}
$$

$\left\{\begin{array}{l}d M_{A} \\ d M_{C} \\ d M_{A} \\ d M_{C} \\ d F_{A} \\ d F_{C} \\ d P_{A} \\ d P_{C}\end{array}\right\}=\left[B_{C}\right]\left\{\begin{array}{l}d \theta_{A} \\ d \theta_{C} \\ d r_{A} \\ d r_{C} \\ d u_{A} \\ d u_{C} \\ d v_{A} \\ d v_{C}\end{array}\right\}$

c) Case of Shear Walls

In idealizing a shear wall member by a 'deep column', its treatment is exactly the same as in the case of column members, and the case of idealization by a 'plane element' (Fig. 17-c) follows.

Defining the displacement conversion matrix $\left[A_{W}\right]$ by

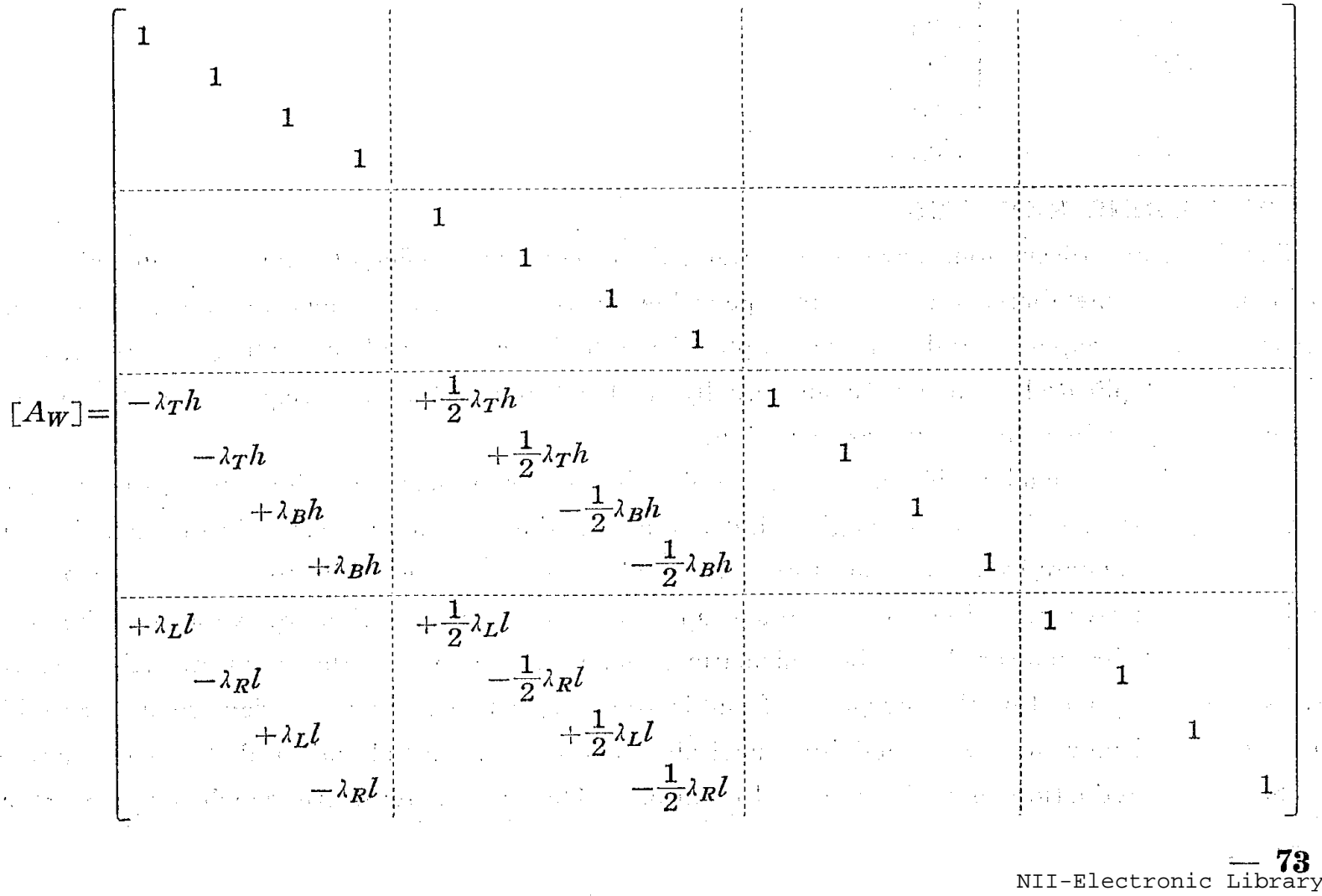


under the assumption that each boundary edge of shear wall is connected at a right angle to beamcolumn connections, and noting the relations

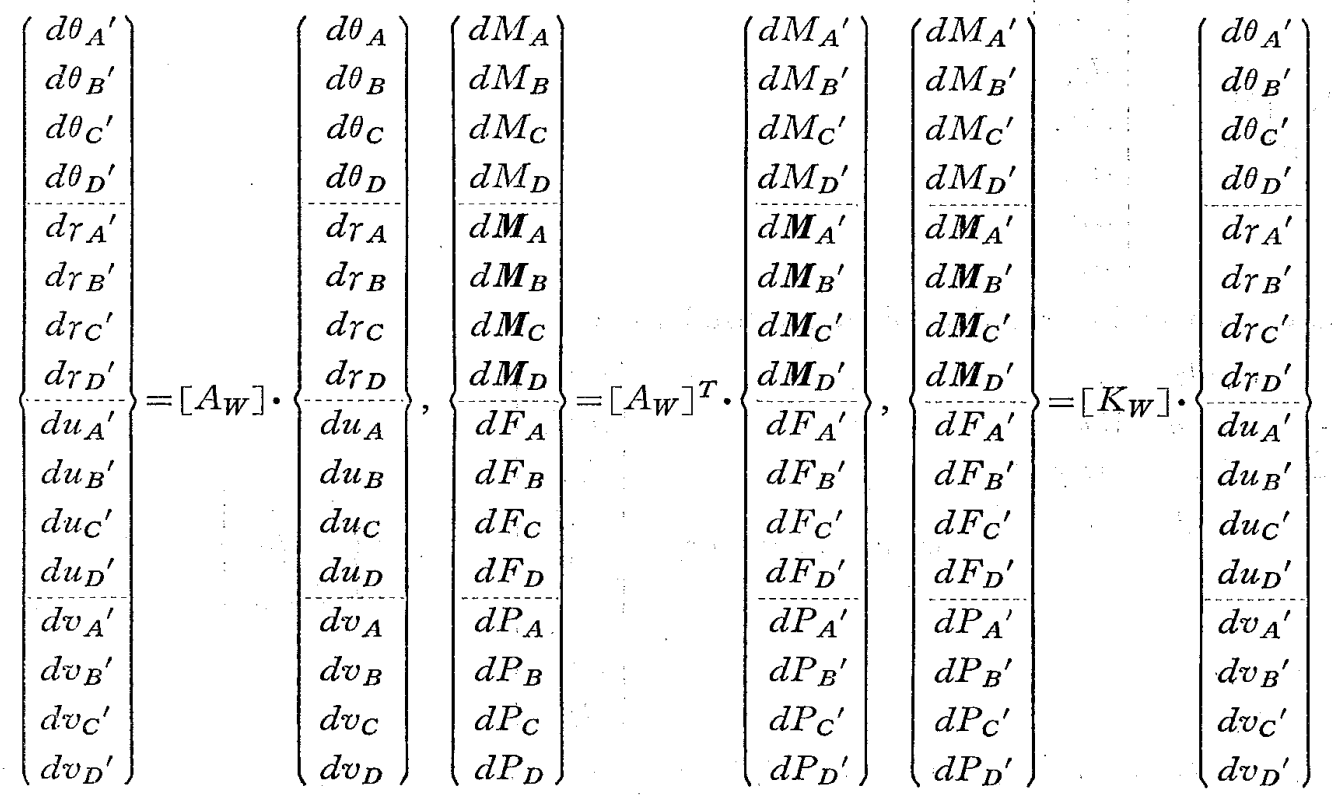

the global stiffness matrix of shear-wall plane element $\left[B_{W}\right]$ is likewise derived:

$\left[B_{W}\right]=\left[A_{W}\right]^{T}\left[K_{W}\right]\left[A_{W}\right]$

$$
\left(\begin{array}{l}
d M_{A} \\
d M_{B} \\
d M_{C} \\
d M_{D} \\
d M_{A} \\
d M_{B} \\
d M_{C} \\
d M_{D} \\
d F_{A} \\
d F_{B} \\
d F_{C} \\
d F_{D} \\
d P_{A} \\
d P_{B} \\
d P_{C} \\
d P_{D}
\end{array}\right\}=\left[B_{W}\right] \cdot\left\{\begin{array}{l}
d \theta_{A} \\
d \theta_{B} \\
d \theta_{C} \\
d \theta_{D} \\
d r_{A} \\
d r_{B} \\
d r_{C} \\
d r_{D} \\
d u_{A} \\
d u_{B} \\
d u_{C} \\
d u_{D} \\
d v_{A} \\
d v_{B} \\
d v_{C} \\
d v_{D}
\end{array}\right\}
$$

\section{CONCLUDING REMARKS}

The foregoing discussions have been intended to construct efficient nonlinear models of structural constituent members. These are indispensable as the bridges connecting the inelastic member properties, known experimentally under simplified single-degree-of-freedom loading condition, and those under more complicated condition in an actually loaded frame, which are required in the process of structural analysis in a highly inelastic region.

Inelastic beam model problem, which occupies the most significant position among the above several bridges, was first examined by arranging and extending the various inelastic beam models thus far proposed into a generalized representation form. This makes it possible to discuss the mechanical validity of respective modelings in a unified and detailed manner. This question on the modeling validity cannot be answered in the affirmative, since the experimental data available at present unsatisfactorily poor for the purpose of subjecting the various beam models to any suitable are comparison, and moreover, any modeling inevitably involves substantial and fatal drawback accompanying the drastic reduction of inelasticity information. However, a tentative conclusion was shown to 
be derived on the inappropriateness of some of the proposed modeling techniques, judging from the definite differences in stiffness reduction properties, which are clarified when such models are subjected to some particular loading conditions.

Next, two additional techniques to this inelastic beam modeling were proposed for the purpose of taking into consideration the influence of initial stress due to dead and live loads, and the time-dependent effect of inelastic characteristics caused by fluctuation of column axial force. In the last section, notes were presented on the mechanical treatment of beam-to-column connections, with main emphasis on introducing the panel distortional moment in a definite way and making its mechanical meaning clear, and further on the associated conversion of the representation form of member characteristics into the expression in terms of generalized forces and displacements defined at each panel point.

\section{ACKNOWLEDGMENTS}

The content of this paper constitutes part of the author's Doctoral Thesis submitted to the University of Tokyo under the supervision of Professor Hajime Umemura. The author wishes to express his deepest gratitude to the Professor and Associate Professor Hiroyuki Aoyama for their continuous encouragements and valuable suggestions offered during the course of the study.

\section{REFERENCES}

1) H. Aoyama : "Inelastic analysis of R.C. frames (1st report)," Trans. AIJ, Extra, Oct., 1967, pp. 357.

2) H. Aoyama and T. Sugano: "A generalized inelastic analysis of R.C. structures based on the tests of members," Recent Researches of Structural Mechanics-Contribution in Honor of the 60th Birthday of Prof. Y. Tsuboi, Uno-Shoten, Tokyo, 1968, pp. 15-30.

3) H. Aoyama, T. Sugano and K. Tani : "Inelastic analysis of R.C. frames," 2nd report, Proc. Kanto Dist. Symp., AIJ, June, 1968, pp. 315-318; 3rd report, Trans. AIJ, Extra, Oct., 1968, pp. 789-790; 4th report, Trans. AIJ, Extra, Aug., 1969, pp. 517-518.

4) T. Sugano: "Inelastic analysis of R.C. buildings with shear walls," Trans. AIJ, Extra, Aug., 1969, pp. 543544 ; Proc. Kanto Dist. Symp., AIJ, Nov., 1969, pp. 73-76.

5) T. Sugano: "Analytical study on the aseismicity of R.C. buildings," Doctoral Thesis, Univ. of Tokyo, Dec., 1969.

6) H. Umemura and H. Aoyama : "Evaluation of inelastic seismic deflections of R.C. frames based on the tests of members," Proc. 4-WCEE, Vol. 1, Ses. B-2, Santiago, Chile, Jan., 1969, pp. 91-108.

7) T. Endo : “Inelastic charactritics of R.C. frames"' Doctoral Thesis, Univ. of Tokyo, Dec,, 1968.

8) S. Sugano: "Experimental studies on the restoring force characteristics of R.C. members," Doctoral Thesis, Univ, of Tokyo, Dec., 1972.

9) S. Sugano: "Study on the restoring force characteristics of R.C. members," Concrete Journal, JANACC, Vol. 11, No. 2, Feb., 1973, pp. 1-9.

10) S. Sugano and I. Koreishi : "An empirical evaluation of inelastic behavior of structural elements in R.C. frames subjected to lateral forces," Proc. 5-WCEE, Vol. 1, Ses. 2-D, Rome, Italy; June, 1973, pp. 841-844.

11) H. Takizawa: "Analysis of the behavior of building structures during strong earthquakes," Doctoral Thesis, of Tokyo, Univ. Dec., 1973.

12) H. Umemura and H. Takizawa: "Inelastic response analysis of $\mathrm{R} / \mathrm{C}$ frames based on inelastic characteristics of constituent members," Proc. Kanto Dist. Symp., AIJ, Jan., 1972, pp. 145-152.

13) H. Umemura, H. Takizawa et al. : "Strong-motion response analysis of R/C frames," 1st \& 2nd reports, Trans. AIJ, Extra, Oct., 1972, pp. 621-624; 3rd \& 4th reports, Proc. Kanto Dist. Symp., AIJ, Mar., 1973, pp. 105112 ; 5th report, Trans. AIJ, Extra, Dec., 1973, pp. 791-792.

14) H. Takizawa : "Strong-motion response analysis of $\mathrm{R} / \mathrm{C}$ buildings," Concrete Journal, JANACC, Vol. 11, No. 2, Feb., 1973, pp. 10-21.

15) H. Umemura, H. Aoyama and H. Takizawa : "Analysis of the behavior of R.C. structures during strong earthquakes based on empirical estimation of inelastic restoring force characteristics of members," Proc. 5WCEE, Vol. 2, Ses. 6 B, Rome, Italy, June, 1973, pp. 2201-2210.

16) H. Takizawa, "Non-linear models for simulating the dynamic damaging process of low-rise R/C buildings during severe earthquakes," Earthquake Engineering \& Structural Dynamics, Vol. 4, No. 1, 1975, pp. 73-94.

17) R.W. Clough, K.L. Benuska and E.L. Wilson : Inelastic earthquake response of tall buildings," Proc. 3WCEE, Vol. II, New Zealand, Jan., 1965, pp. 68-89.

18) R.W. Clough and K.L. Benuska : "FHA study of seismic design criteria for highrise buildings," HUD TS-3, Federal Housing Administration, Wash. D.C., 1966.

19) M.F. Giberson : "The response of nonlinear multi-story structures subjected to earthquake excitation," Earthq. Engng. Res. Lab., Calif. Inst. Tech., Pasadena, 1967.

20) M.F. Giberson: "Two non-linear beams with definitions of ductility," Proc. ASCE, Vol. 95, No. ST 2, 1969, 
pp. 137-157.

21) S. Otani, and M.A. Sozen : "Behavior of multi-story R.C. frames during earthquakes," Univ. of Illinois, Urbana, Nov., 1972.

22) S.C. Goel : "Inelastic behavior of multistory building frames subjected to earthquake motion," Univ. of Michigan, Ann Arbor, Dec., 1967.

23) S.C. Goel and G.V. Berg: "Inelastic earthquake response of tall steel frame," Proc. ASCE, Vol. 94, No. ST 8, 1968, pp. 1907-1934.

24) W.R. Walpole : "The response of structures to earthquake loading," Univ. of Canterbury, Christchurch, New Zealand, 1968.

25) W.R. Walpole and R.S. Shepherd : "The inelastic response of steel frame," Proc. 4-WCEE, Vol. II, Ses. A4, Santiago, Chile, Jan., 1969, pp. 195-204.

26) W.R. Walpole and R.S. Shepherd : "Elasto-plastic seismic response of R.C. frame," Proc. ASCE, Vol. 95, No. ST 10, 1969; pp. 2031-2055.

27) R.W. Clough and K.L. Benuska : "Non-linear earthquake behavior of tall buildings," Proc. ASCE, Vol. 93, No. EM 3, 1967, pp. 129-146.

28) J.C. Anderson and V.V. Bertero," Seismic behavior of multistory frames designed by different philosophies," Earthq. Engng. Res. Center, Univ. of Calif., Berkeley, Oct., 1969.

29) H. Aoyama, J. Kato and M. Yoshimura : "Inelastic analysis of R.C. frames; Part 5 : Method of analysis in consideration of the influence of column axial force on the stiffness," Trans. AIJ, Extra, Nov., 1971, pp. 10051006 ; Proc. Kanto Dist. Symp., AIJ, Jan., 1972, pp. 137-140.

30) M. Suko and P.F. Adams : "Dynamic analysis of multibay multistory frames", Proc. ASCE, Vol. 97, No. ST 10, 1971, pp. 2519-2533.

31) Y. Omote, T. Takeda et al. : Comprehensive method of analysis for building structures; Part 3 : Inelastic response analysis of flexural-failure-type buildings," Trans. AIJ, Extra, Sept., 1970, pp. 303-304.

32) Y. Omote : "Development of aseismatic design program for highrise buildings," Kenchiku Gijutsu (ed. by Building Res. Inst:), No. 245, Jan., 1972, pp. 173-182.

33) T. Takeda and K. Yoshioka: "Response analysis of one-storied multi-bay frames (1st report)," Proc. Kanto Dist. Symp., AIJ, Jan., 1972, pp. 133-136.

34) K. Yoshioka, T. Talkeda and K. Nakagawa : "Inelastic earthquake response of R.C. buildings," Proc. 5-WCEE, Vol. 2, Sec. 6 B, Rome, Italy, June, 1973, pp. 2172-2181.

35) Y. Matsushima : "Experimental study on 5-story full scale apartment house with R.C. walled frames," Concrete Journal, JANACC, Vol. 8, No. 1, Jan., 1970, pp. 11-21.

36) S. Kokusho et al. : "Study on deformation characteristics of flexural-failure-type R.C. frames subjected to reversal of lateral load; Part 2 : Deformation analysis of R.C. frames subjected to reversal of lateral load," Proc. Kanto Dist. Symp., AIJ, Jan., 1971, pp. 101-104.

37) K. Noguchi : "Study on inelastic earthquake response analysis of R.C. frames," Master Thesis, Tokyo Inst. Tech., 1971.

38) H. Umemura, H. Aoyama and T. Endo: "Strength and stiffness of R.C. beam-column connections (Approximate estimation of inelastic structural deformation)," Trans. AIJ, Extra, Sept., 1965, pp. 206.

39) T. Sugano : "Matrix method of structural analysis in consideration of shear deformation of beam-column connections," Proc. Kanto Dist. Symp., AIJ, June, 1968, pp. 311-314; Trans. AIJ, Extra, Oct., 1968, pp. 563-564. 


\section{RC 造平面架構の弾塑性解析における 基本的諸問題に関するノート（梗概）}

（第二部）

正会員滰沢春男决

本諭文は，構造物を構成する各部材要素に刘する非線 形モデル化手法に関連して，いくつかの基本的な問題に ついて議論したものであり，二部から構成される。これ らの議諭は，鉄筋コンクリート造建物の強震時に於ける 動的弹塑性挙動を，その構成部材レベルでの特性から明 らかにし，各構成部材の損傷過程の追跡を通じ，その動 的崩壊過程をシミュレートする目的で，構造物全体系を 平面架構ししての動的非線形系に理想化する際の基整を 提供するもので岁る。ここで論じるモデル化手法は, 部 材実験を通じて予的直接規定し得る, 単純な載荷条件下 (一自由度載荷) での，各構成部材の弾塑性性状一復元 力特性（これらは一般には，例えば，既に提案されてい る一連の実験式群を参照する事により，評価される） 々，構成部材レベルでの特性に直接立脚した，高度の非 線形領域での構造物・弹塑性解析の具体的なプロセスの 各段階に於いて逐一評価されるべき，現実の架樍中に組 み込まれた状態での，上り複雑な載荷条件下（多自由度 載荷での応力状態）に於ける復元力特性, との間に存在 する大きなギャップを埋め，その間を結ぶ必要不可欠な 架け橋を構築しょう，という特定の意図の下に展開され る。このよらなモデル化手法が具体的に確立されれば， 各時点での構造物全体系の非線形特性を, 部材実験結果 の性状に忠寒な形で完全に評価する事がはじめて可能に なり，強震時におけるその動的崩壊をもたらす詳しいプ 口セス，つまり特定の地震動外乱の作用下に晾ける各满 成部材の損傷程度の時間的推移を，単に数值計算によ。 て時々刻々追跡し得る事になる。又，このような形式で の虑答解析の結果判明する各部材要素の損傷工合を, 逆 に, 実験室での刘応する部材実験のそれに直接対比させ る事が出来, 地震被害を部材実験結果に結びつけて考察 する事が，可能となる。本諭での議論は，以上述べた目 的の達成に拈いて最も重要な役割を演じる，いわゆる

「ビームモデル」論に重点を打き展開される。

この弾塑性ビームモデル問題を諭じるために，まづ, これ迄に提案され現実の構造解析に採用されて来た種々

* 北海道大学工学部建築工学教空

（昭和 49 年 8 月 12 日本稿受理・討論期限眧和 51 年 6 月末日）
のビームモデルを，各々のモデル化が拠って立つ仮定条 件が明確になり，その力学的妥当性を統一的な形で詳細 に比較・吟味する事が可能になるように，一般的な表現 形式に昖張あるいは整理する事は，既に本論の第一部に 於いて実行された。ビームモデルの妥当性に関するこの 設問に刘する解答は，これらの種々のモデルについての 適当な比較・検討にたえ得るだけの部材実験結果の集積 が現状では極めて貸弱であり，更に，いら゙れのビームモ デル化手法も，部材の弹塑性情報の極度の減少化に伴な い，必然的に或る種の本質的な久宿を有するが故に，断 定的な形では 与古る事が出来ない。しかし，一心の結 論，少なくとも，既に提案され使用されているビームモ デルのらちのいくつかの少的不合理さ, モデルとして の不完全性法，これらのモデルが特定の条件下で載荷さ れる場合に明白になる，剛性低下特性の相違に基づい て，容易に指摘し得る事が示される。

次には，このビームモデル化手法に関しして付随する 二つの付加的手法が提案される。一つは, 特に梁部材で 問題となる，常時荷重による初期応力がおよぼす影響を 考慮するための手法に関連するものであり，他の一つ は, 柱軸力の地震時変動に伴なら, 柱部材弾塑性性状の 時間依存性効果の考慮に関する取り扱いについての手法 である。

又, 最後に, 柱・梁接合部の力学的取り扱いに関する ノートが提示される。そこでは，今迄，極めて不明確な 形で取り扱われていた「パネル(剪断) モーメント」(接 合部の剪断変形に関与するモーメント）を明快な形式で 導入し，その力学的意味を明瞭にする事に力点が置かれ た詳論が展開され，更に，この接合部のモデル化に伴な う, 各部材要素特性の表現形式の変換（各部材レベルで 表現されて来た瞬閪剛性を，各節点で定義される広義の 変位と広军の力の立場加らの表現に変換する）について 述べる。本論文の内容は, 平面架搆の揚合に限定されて いるが，立体架構に拈ける構造部材の非線形モデル化 (平面架構の場合と同様に，部材実唋結果の復元力特性 に，その基礎をおくりに関する同種の議論については， 機会を改めて報告する。 